\title{
A LANGUAGE ASSESSMENT ANALYSIS OF ENGLISH NATIONAL EXAMINATION IN INDONESIA
}

\author{
Arini Sabrina \\ Semarang State University \\ Semarang, Indonesia \\ arinisabrina91@gmail.com
}

\begin{abstract}
By virtue of the importance and the gradual development of national examination in Indonesia, this article evaluates its implementation, focusing on English subject through the perspective of language assessment. The analysis of this qualitative research is placed initially on the quality of questions of English national examination in the academic year of 2014-2015 for senior high schools. After the question quality analysis, there is a subsequent analysis focusing on assessing the outer aspect in dealing with the English national examination implementation in Indonesia which is the regulation itself. The results show that some weaknesses still emerge regarding the quality of both the text the questions, also the aspects outside those ones like the impacts of the regulation towards the students and the schools.
\end{abstract}

Keywords: English, national examination, language assessment

\section{INTRODUCTION}

A big commitment has been shown by the government of Indonesia in conducting the qualified national examination through offering some renewed strategies, especially in the academic year of 2014-2015, one of which is by stating that national examination is no longer to be the benchmark for the students' chance to graduate from their schools. Through some revisions, the government hopes that the students do not feel burdened with all of the demanding requirements. Moreover, it is also expected that the stereotype attached to national examination as nightmare for the students as it is the only way for them to be able to graduate from their schools can diminish.

English is one of the subjects tested in the examination, especially for the senior high school students. This subject might be regarded as complicated matter faced by the students, because it is foreign language instead the first or second language for most students in Indonesia. Besides, it comprises four skills having bunches of sub-skills that the students need to 


\section{EduLite}

Journal of English Education, Literature, and Culture

master, although there is no speaking test in the national examination. As a consequence, a good English assessment is required.

This article scrutinizes the goods and bad from both the inner and outer aspects of English national examination in the academic year of 20142015 for senior high schools in Indonesia. It highlights the quality of all the questions and some other aspects like formula to determine whether the students both pass the examination and graduate from the school or not, the impact of national examination for the schools and local government.

Language assessment, then, becomes a base in analyzing the national examination. Based on its importance, language assessment has many principles which must be considered in order to support it as the best and the most suitable assessment for the students. Green (2014: 58) also Farhady in Coombe, et al. (2012: 37) explain that there are at least three qualities of a language assessment. Those are practicality, reliability, and validity. Brown (2000: 31-37) explains that there are six questions in evaluating the test. Those are as follows:
a. Are the test procedures practical?
b. Is the test reliable?
c. Does the procedure demonstrate content validity?
d. Is the procedure face valid and "biased for best"?
e. Are the test tasks as authentic as possible?
f. Does the test offer beneficial wash-back to the learner?

These questions may be a framework in assessing the English national examination in Indonesia. Furthermore, the examination is also based on the regulation that was published by the government recently through Sosialisasi Kebijakan Ujian Nasional Tahun Pelajaran 2014/2015 from BSNP (Badan Standar Nasional Pendidikan).

To be specific, because the analysis focuses on reading and writing tests, there are some types of those tests that can be understood as the categorizations. Started with the reading types, there are four based on Brown (2000: 189). They are perceptive, selective, interactive, and extensive. In perceptive reading, the tasks involve attending to the components of larger stretches of discourse in which bottom-up processing is implied. Then, a selective type is used to ascertain one's reading recognition of lexical, grammatical, or discourse features of language within a very short stretch of 
Sabrina, A Language Assessment Analysis of English National Examination

language. In interactive reading, longer paragraphs are used and interaction between the readers and the text is optimistic. In contrast, the extensive reading seems to make the reading activity joyful, as the students are asked to read the texts of more than a page outside a classroom hour.

Different from reading, writing has also four types: imitative, intensive, responsive, and extensive. The imitative category includes the ability to spell correctly and to perceive phoneme-grapheme correspondences in the English spelling system. In intensive writing, the students are asked to produce appropriate vocabulary within a context, collocations and idioms. Next, responsive writing requires the students to perform at a limited discourse level, connecting sentences into a paragraph and creating a logically connected sequence of two or three paragraphs. The last is extensive writing, which demands the students in composing an essay a major research project, or even a thesis, through some processes of writing (Brown, 2000: 220).

Besides the inner aspects of English national examination, some outer aspects are also examined. These refer to the regulations and the impacts to both the students and the schools. It is important to note that the government publishes a new regulation about national examination. Through a power point file entitled Sosialisasi Kebijakan Ujian Nasional Tahun Pelajaran 2014/2015, the government presents a complete framework for a revived national examination. The first one, the national examination is not regarded any longer as the factor of the students' graduation. The minimum score of each subject is 5.5. Moreover, there is a remedial test for whoever does not attain the minimum score. The last one is the score mapping and description of each sub competency which is tested, besides the score itself.

In relation to the design, this research is qualitative in nature. Language assessment will be the pivot of the analysis, though some considerations of other aspects outside language are also investigated. The analysis will be placed initially on the quality of questions of English national examination in the academic year of 2014-2015 for senior high schools. It is known that there are some sets of English national examination in order to decrease the cheating potentiality done by the students. In practice, the analysis will only be limited to one single set of the English national 


\section{EduLite}

Journal of English Education, Literature, and Culture

Volume 1, Number 2, August 2016

examination, since it suffices the framework of questions based on the blueprints. Moreover, the question set that is analyzed is also limited for the students of social sciences. Then, it needs also to be noted that listening section will not be analyzed, as the focuses of this analysis are reading and writing only. After the question quality analysis, through envisaging the ideal postulates in designing a test, there is a subsequent analysis focusing on assessing the outer aspect in dealing with the English national examination implementation in Indonesia which is the regulation itself.

\section{DISCUSSION}

The analysis initially moves to the reading section. The blueprints are provided below:

\begin{tabular}{|c|c|c|}
\hline & \multirow{7}{*}{$\begin{array}{l}\text { READING (Membaca) } \\
\text { Memahami makna } \\
\text { dalam wacana } \\
\text { tertulis secara } \\
\text { formal maupun dalam } \\
\text { informal kehidupan } \\
\text { konteks dalam } \\
\text { sehari-hari, } \\
\text { bentuk teks } \\
\text { fungsional pendek, } \\
\text { recount, news } \\
\text { item, report, } \\
\text { analytical exposition, } \\
\text { hortatory exposition, } \\
\text { explanation, } \\
\text { discussion dan } \\
\text { review. }\end{array}$} & $\begin{array}{l}\text { Menentukan gambaran umum atau informasi } \\
\text { rinci/tersirat/tertentu atau } \\
\text { kata/frasa/kalimat atau pikiran utama paragraph/ } \\
\text { rujukan kata atau tujuan komunikatif dari teks } \\
\text { fungsional pendek berbentuk letter/e-mail. }\end{array}$ \\
\hline & & $\begin{array}{l}\text { Menentukan gambaran umum atau informasi } \\
\text { tertentu/ rinci/tersirat atau rujukan kata atau makna } \\
\text { kata/frasa dari teks tertulis fungsional pendek } \\
\text { berbentuk advertisement/brochure. }\end{array}$ \\
\hline & & $\begin{array}{lcr}\text { Menentukan gambaran umum atau informasi } \\
\text { tertentu/rinci/tersirat } & \text { atau } & \text { makna } \\
\text { kata/frasa/kalimat atau tujuan komunikatif/ pikiran } \\
\text { utama paragraf/rujukan kata dari teks tertulis } \\
\text { berbentuk news item. }\end{array}$ \\
\hline & & $\begin{array}{l}\text { Menentukan informasi tertentu/rinci/ } \\
\text { makna kata/frasa/kalimat atau } \\
\text { umum/tujuan komunikatif/pikiran utam } \\
\text { rujukan kata dari teks tertulis berbentuk }\end{array}$ \\
\hline & & $\begin{array}{l}\text { Menentukan gambaran umum at } \\
\text { tertentu/ tersirat/rinci atau tujuan kor } \\
\text { makna kata/frasa/kalimat atau ru } \\
\text { pikiran utama paragraf dari teks tert } \\
\text { explanation. }\end{array}$ \\
\hline & & $\begin{array}{l}\text { ran umum atau infor } \\
\text { i atau pikiran utama parc } \\
\text { lfrasa/kalimat atau rujl } \\
\text { atif dari teks tertulis berbe }\end{array}$ \\
\hline & & $\begin{array}{l}\text { ntukan gambaran umum atau info } \\
\text { ntu/ tersirat/rinci atau tujuan komunikatif }\end{array}$ \\
\hline
\end{tabular}


Sabrina, A Language Assessment Analysis of English National Examination

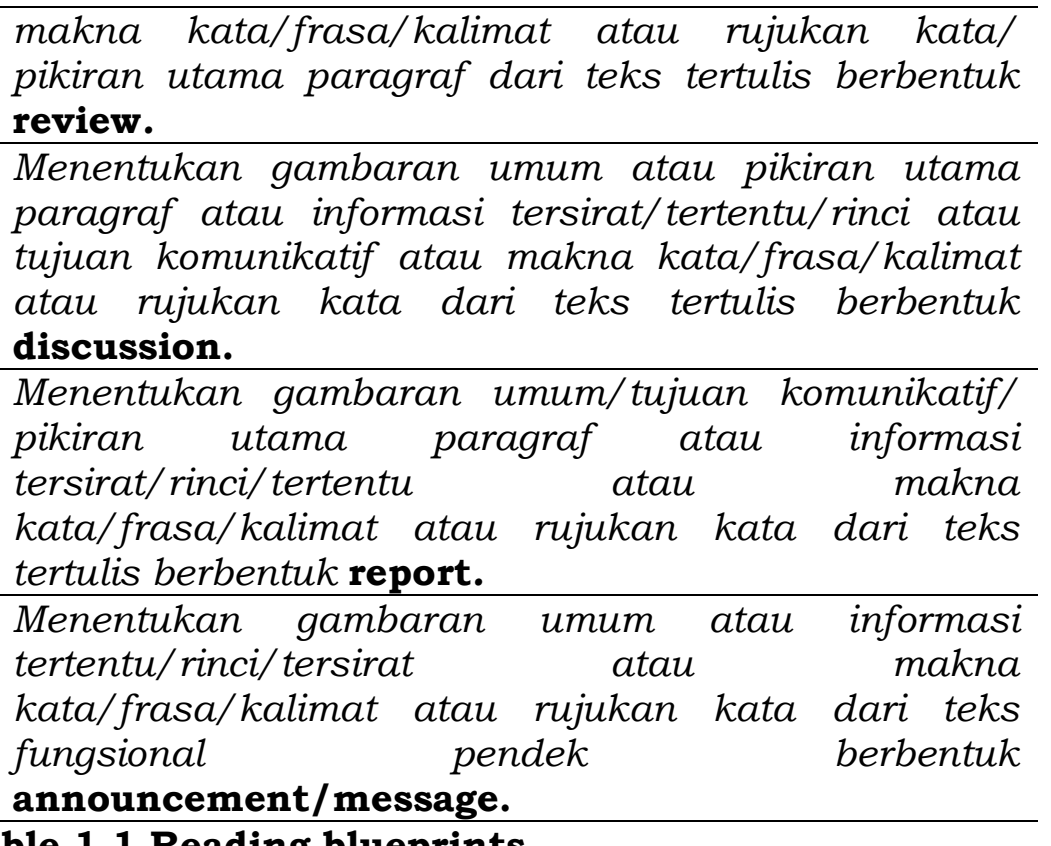

\section{Table 1.1 Reading blueprints}

The first blueprint is determining the general description, or detailed/ implicit/ certain information, or word/phrase/sentence meaning, or word reference/ paragraph main idea, or communicative purpose of a functional text in the forms of either letter or email. The blueprint is then elaborated into the questions 16 and 17 below:

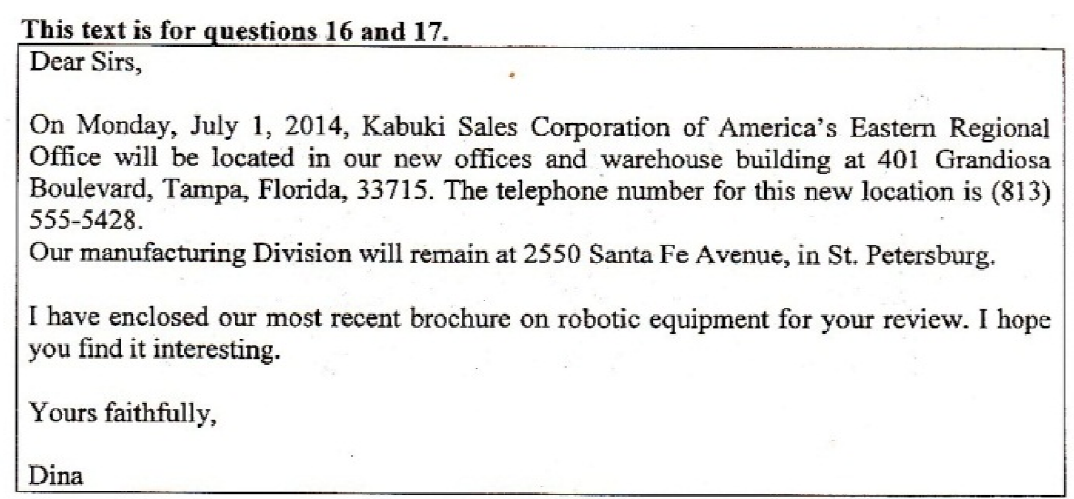

16. How can you get more information?
A. Going to the new office
B. Calling to $813-555-5428$
C. Visiting the warehouse building
D. Coming to Grandiosa Boulevard
E. Sending an e-mail to the corporation

17. We can conclude from the text that ....
A. new building's address is not far from the old one
B. Kabuki Sales Corporation will sell its office buildings
C. the new location of the corporation is on Santa Fe Avenue.
D. the recent brochure is separated from the robotic equipment
E. the Manufacturing Division will not move to the new building

\section{Figure 1.1 Reading questions about letter}




\section{EduLite}

Journal of English Education, Literature, and Culture

Volume 1, Number 2, August 2016

The questions, which can be categorised as interactive reading type, consist of two kinds of blueprints. The first one is scanning the specific information, while the latter is inferring the conclusion. The blueprints then fit the questions, making the students more confident since they have prepared much before. Again, the text is not too long, since the interactive reading type in fact requires the text that is moderately short. Besides, the students in this text are also demanded to do top-down processing in which they can comprehend the text thoroughly, not processing separate letters or words. This can be regarded suitable for the students of senior high schools.

Unfortunately, there is no information about who makes the text. Ideally, a good text is the one which is contextual and made by the native speakers. This second requirement is based on the assumption that native speakers' writing will show the original delivery of diction, structure, even culture to that support the contextual matter. My suggestion is that, the text can be taken or even adapted from original sources like magazines, etc. After that, the source can be attached below the text.

An advertisement becomes the next thing discussed. The further information is provided below:

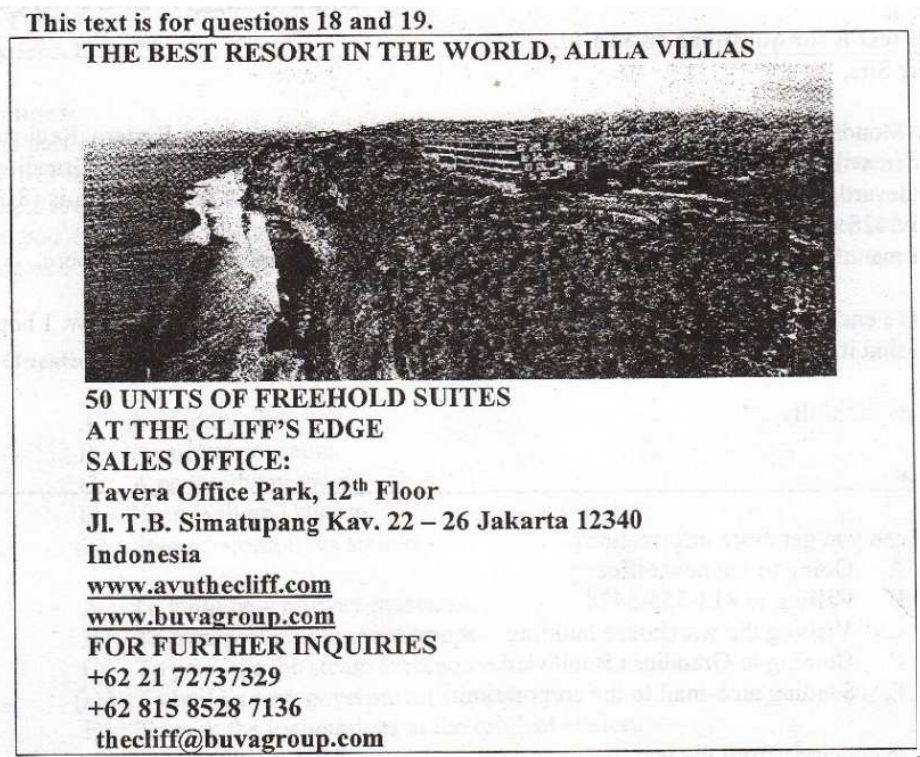

18. What is the advertisement about?
A. Alila Villas
B. Cliff's edge
C. Sales Office
D. Hotel Resort
E. Freehold suites

19. Write an e-mail to ... if you need further information.
A. Alila Villas
B. +622172737329
C. Tavera Office Park
D. www.avuthecliff.com
E. thecliff@buvagroup.com

Figure 1.2 Reading questions about advertisement 
From the figure above, apart from the absence of the source of the text, it can be concluded that the first question asks about the general description, while the second one searches for the certain information. At a glance, the students are helped with the cue from question number 18, stating the text as advertisement explicitly. This facilitates the students in thinking of some points like the communicative purpose or what is advertised. Different from number 18, question number 19 requires the students to infer the e-mail address to get the further information. Fortunately, email is very common in Indonesia, particularly after Facebook and other social media which require the users to have email account conquer the online communication usually accessed by teenagers. However, sometimes the students who hurry in choosing the answer might choose the website address instead of email address. This is because the similarity between them; they are ended with .com. In fact, the website address, which can be also called as distraction, is a component of good question. It is said so as a good question if it not let the test taker easily get the answer. Rather, a good question, especially the multiple-choice one, will provide some distraction to keep the quality.

The next blueprint is finding information on news item. As the name, the text is usually characterized with lengthy passage, as displayed below:

Jakarta, Wed. Many people are closely, following the political polls during the final weeks preceding this important general election. But how do these polls actually work?

"Polls are surveys of a relatively small number of people compared to the actual number who will vote. They are to predict who may actually win an election before the final vote," said a politic observer, Muhammad Faishal.

Let's say that 100 million people are expected to vote in the general election. If 100 people are asked for their opinions, each respondent represents a million voters, Faishal emphasized further, "It is obvious, the results of such a poll are not very reliable. The more people surveyed, the more meaningful are the results."

Pollsters have various ways of making their polls more accurate. They try to find a representative of variety of people to question. For example, they look for people with similar backgrounds and from similar regions to those of all the voters.

Pollsters also ask questions that try to find how many people who support each candidate will actually vote. If a candidate has a higher percentage of enthusiastic supporters than his opponent, he has a better chance of winning than the low numbers might suggest. Pollsters may only count those who they consider to be "likely voters."

If we look at the polls that are taken over time, we can often detect a trend. We can tell if a candidate is gaining or losing support when we compare with the most recent polls to the earlier ones.

Polls often ask potential (those who could be) voters what they like or dislike about each candidate. The campaigns use those results to help them decide which issues to stress or which positions to clarify. They can also determine which voters to target with their messages.

"Because no two people are the same, polls can never be perfect predictors of the real vote. But they can give important clues as to where things may be heading. At the very least, if you like politics, polls can be great entertainment," Faishal said. (The News) 


\section{EduLite}

20. Which of the followings is the most suitable title for the text?
A. Political Polls.
B. General Election.
C. Perfect Predictors.
D. Reliable Poll Result.
E. Enthusiastic Voters.

21. We can infer from the text that ....
A. pollsters may mislead people's opinion
B. polls can predict precisely about the voters
C. polls are an effective way to do a political campaign
D. voters may have chances to support the winning candidate earlier
E. the more people involved in a poll, the more reliable the results will be

22. What is the main idea of paragraph 4 ?
A. Pollsters ask questions to similar people.
B. Pollsters have various ways to get more accurate results.
C. Voters are people of similar background and similar regions.
D. A representative of variety of people is chosen to ask questions.
E. The responses people with similar background and similar regions are reliable.

\section{Figure 1.3 Reading questions about news item}

There are three questions connected with news item, each of which brings different blueprint option. The question Number 20 demands the students to comprehend the text and choose the best title to describe the text generally. The question number $21^{\text {st }}$ one is about inferring or decoding the implicit information, while the question number 22 asks the main idea of certain paragraph.

For the quality of questions, I argue that, although the delivery and the content of question number 20 are good, it lacks good distraction. All of the paragraphs inside talk about political polls, and it will be easy for the students to get the main idea of the text. Nonetheless, it should be noted that there are components in making a good test, in which the questions are balanced among the easy, moderate, until difficult ones in one portion.

Questions number 21 and 22 have different levels of difficulty. The question number $21^{\text {st }}$ demands the students' deep understanding to infer something, the question number $22^{\text {nd }}$ has explicit answer which can be easily scanned by the students in the first sentence as the main idea. The correct answer (b) is tried to be a relaxer, but not so much. Therefore, the students can find the answer without being attracted to choose the other options.

The next text is also news item which has three questions. From these three questions, it can be concluded that the difficulty level of each question 
increases, compared to the prior three questions. The questions, which focus on generating the main idea of the text; finding specific information; and inferring information from a certain paragraph, have the students to think deeper in order to find the right answer, as scanning is not really helpful in this case. Instead, understanding the whole text evenly is urged here. In addition to the question type, the answer options are also similar, but not the same. This, as a consequence, adds one point to support the quality of the questions. But, a weakness is also seen from the lack of the detailed source of the text taken. The text and the complete questions are as follows:

This text is for questions 23 to 25 .

Multinational Crystal Lagoons will mark its return to Cityscape in Dubai with the launch of its latest and grandest project to date, which onco completed will be entered into the Guinness Book of World Records.

The developer of the giant crystalline lagoons has signed a deal to construct the world's largest man-made lagoon, covering 40 hectares, almost four-times bigger than the world's largest existing lagoon. Located in the upscale Mohammad Bin Rashid City - District One residential community, in the heart of Dubai, the lagoon will form an integral part of the US\$7 billion project.

Mohammad Bin Rashid City - District One is a prestigious joint venture between Dubaibased Meydan Group and Real Estate developer, Sobha Group. The new lagoon with its expansive custom-made beaches, which offer unlimited scope for swimming, water sports and other water based leisure activitics, will be a core amenity within Mohammad Bin Rashid City - District One's 47 million square feet of freehold land.

The expansive development will feature luxury residences, green parklands, waterways, a high end shopping and dining pavilion and large recreational spaces creating one of the lowest density developments in the heart of any international city.

"Caribbean landscapces are no longer exclusive to tropical destinations.

"Our pioneering concept and state-of-the-art technology, which allows for sustainables, swimmable, turquoise lagoons of unlimited sizes to be built and maintained at low cost anywhere in the world, is proving extremely popular with our growing list partnerts across the Middle East" said Kevin Morgan, chief executive of Crystal Lagoons. (News : Business)

23. The text is mainly about ....
A. the project of the giant crystaline lagoons.
B. the launch of the project buildings in the world.
\&. the project of the world largest man-made lagoon.
D. the development of the lagoons in the world.
E. the development of the giant crystalline lagoon.

24. What is the aim of developing an outstanding lagoon?
A. To implement the art of high technology.
B. To explore the glory of the lagoon to the world.
C. To attract tourists from all over the world to come.
D. To breakdown the popularity of the Caribbean landscapes.
E. To meet the need of the Middle East people for recreation.

25. From the third paragraph, we imply that ....
A. the world's largest existing lagoon is luxurious.
B. the lagoon forms an united part of billion budget.
C. the largest development features luxury residences.
b. the new lagoon offers unrestricted spaces for sports.
E. the large recreation spaces create the lowest density development.

Figure 1.4 Reading questions about news item 


\section{EduLite}

Journal of English Education, Literature, and Culture

Volume 1, Number 2, August 2016

The next three questions are in relation to a recount text telling about Lionel Messi's life (biography). As it is recount, the diction are not so difficult to understand. Also, the questions are not so demanding, especially for the first question, which is about the communicative purpose of the text. As recount becomes the only one kind of tested text which plays past tense, the students can easily find the answer for the purpose of its delivery, especially about biographv. The further displav is given below:

This text for questions 26 to 28.

Lionel Messi (Luis Lionel Andres Messi) was born on June 24, 1987, in Rosario, Argentina. As a young boy, he tagged along when his two older brothers played soccer with his friends, unintimidated by the bigger boys. At the age of 8 , he was recruited to join the youth system of Newell's Old Boys, a Rosario-based club. Recognizably smaller than most of the kids in his age group, Messi was eventually diagnosed by doctors as suffering from a hormone deficiency that restricted his growth.

Messi's parents decided on a regimen of nightly growth-hormone injections for their son, though it soon proved impossible to pay several hundreds dollars per month for the medication. So, at the age of 13 , when Messi was offered the chance to train at soccer powerhouse FC Barcelona's youth academy, La Masia, and have his medical bills covered by the team, Messi's family picked up and moved across the Atlantic to make a new home in Spain.

By the age of 16, Messi had made his first appearance for Barcelona. He put himself in the record books on May 1, 2005, as the youngest player ever to score a goal for the franchise. Messi steered Barcelona to a wealth of succes, most notably in 2009. Amazingly, the diminutive soccer wizard continue to improve, discovering new ways to elude defenders while leading Barcelona to La Liga and Spanish Super Cup championship in 2010 and 2011, as well as the Champions League title. Messi embarked on an all-out assault on the record books in 2012. He became the first player to score five goals in a Champion League match in early March, and a few weeks later he surpassed Cesar Roriguez's club-record 232 goals to become Barcelona's all-time leading scorer. By the end of 2012, Messi had accumulated an astounding 91 goals in club and international play. Fittingly, he broke one more record when he was named the FIFA Ballon d'Or winner for the fourth time in January 2013.

26. What is the text about?
A. FIFA Ballon d'Or Winner.
B. Lionel Messi's life in brief.
C. Messi's reputation in FC Barcelona.
D. Messi's reputation in Football match.
E. The Messi's recovery from his hormone deficiency.

27. Why did Messi leave for Spain?
A. The doctor diagnosing him was in Spain.
B. He had the manager pay the medical bills.
C. He wanted to perform his appearance in Barcelona.
D. He moved across the Atlantic to make a new home in Spain.
E. He was given the opportunity to be trained at a soccer academy.

28. From the text, we conclude that Messi's ... will lead him to be one of the most famous soccer player in the world.
A. fortune
B. biography
C. personality
b. achievement
E. competition

Figure 1.5 Reading questions about recount 
Explanation becomes the following text discussed. A text, although without source from which the text is taken, is given about gelatin. The text itself has been cohesively and coherently created, making the readers understand it more easily. Unfortunately, there is one question which is prone to be confusing. The question number 29 asks the students to find the first way in eliminating the grease from the bones. However, there is no information at all. Instead, the available one is the next steps after eliminating the grease. This question, then, should be reviewed by the government, though there is no problem with the other questions related. The complete data are presented below:

This text is for questions 29 to 31 .

Gelatin is a protein substance that comes from the skins and bones of animals. Most people know it as the substance used to make a jellylike salad or dessert. Not only is it useful in making these foods, but it is also beneficial to the consumer because of its high protein content. Gelatin is also commonly used in the photographic industry and in making medicinal capsules.

The process for producing gelatin is a long and complex one. In the processing of gelatin made from bones, which varies slightly from that of gelatin made from skin, the grease first must be eliminated. Then, the bones are soaked in a solution of hydrochloric acid in order to rid them of minerals and then washed several times in water.

Next, the bones are placed in distilled water, heated to over $90^{\circ} \mathrm{F}$ for a few hours, placed in fresh distilled water, and then heated again at a little over $100^{\circ} \mathrm{F}$. A fluid forms from this heating, and it is concentrated, chilled and sliced. Finally, it is dried and ground. In its final form gelatin is white, tasteless, and odourless.

29. What is firstly done to eliminate the grease from the bones?
A. Soaking the bones in a solution of hydrochloric acid.
B. Concentrating the fluids formed with heating
C. Grinding the bones after being heated.
D. Placing the bones in distilled water.
E. Washing the bones several times.

30. What is the main idea of the second paragraph?
A. Gelatin consists of protein.
B. Gelatin is only produced from skin.
C. We can make gelatin in a simple way.
ø. The processs of producing gelatin is very complex.
E. Fresh water is very important in producing gelatin.

31. "Next, the bones are placed in distilled water, heated to over $90^{\circ} \mathrm{F}$ for a few hours, ..." (Paragraph 3)

The underlined word is closest in meaning to ....
A. boiled
B. purified
C. steamed
D. polluted
E. contaminated

Figure 1.6 Reading questions about explanation 


\section{Edulite}

Journal of English Education, Literature, and Culture

Volume 1, Number 2, August 2016

There are also some problems found in the discussion text delivered for number 32 up to 34 . When we consider the blueprints as the ordered one, the discussion text should be located after review, not explanation. Then, ideally, a text can be regarded as a good text when it consists of paragraph having not only one single sentence. In fact, in the text attached below, the first and the last paragraph have only one sentence. Brandon and Brandon (2014: 286), Connelly (2013: 29), also Wingersky, et al. (2009: 29) support it by arguing that a paragraph is a group of sentences, each with the function of stating or supporting a single controlling idea that is contained in the topic sentence. It is different from news item which is usually free in writing, meaning that the news writers have their own special writing format.

Apart from the format, the questions and the options are well and clearly formed. The questions are related to the content and the blueprint, asking about specific information, finding the main idea of a paragraph, and inferring the suggestion. Moreover, the answers are also good, considered to have qualified distraction. Good distraction can make the questions not so easy for the students and require them to think carefully. The further information of the text is as follows:

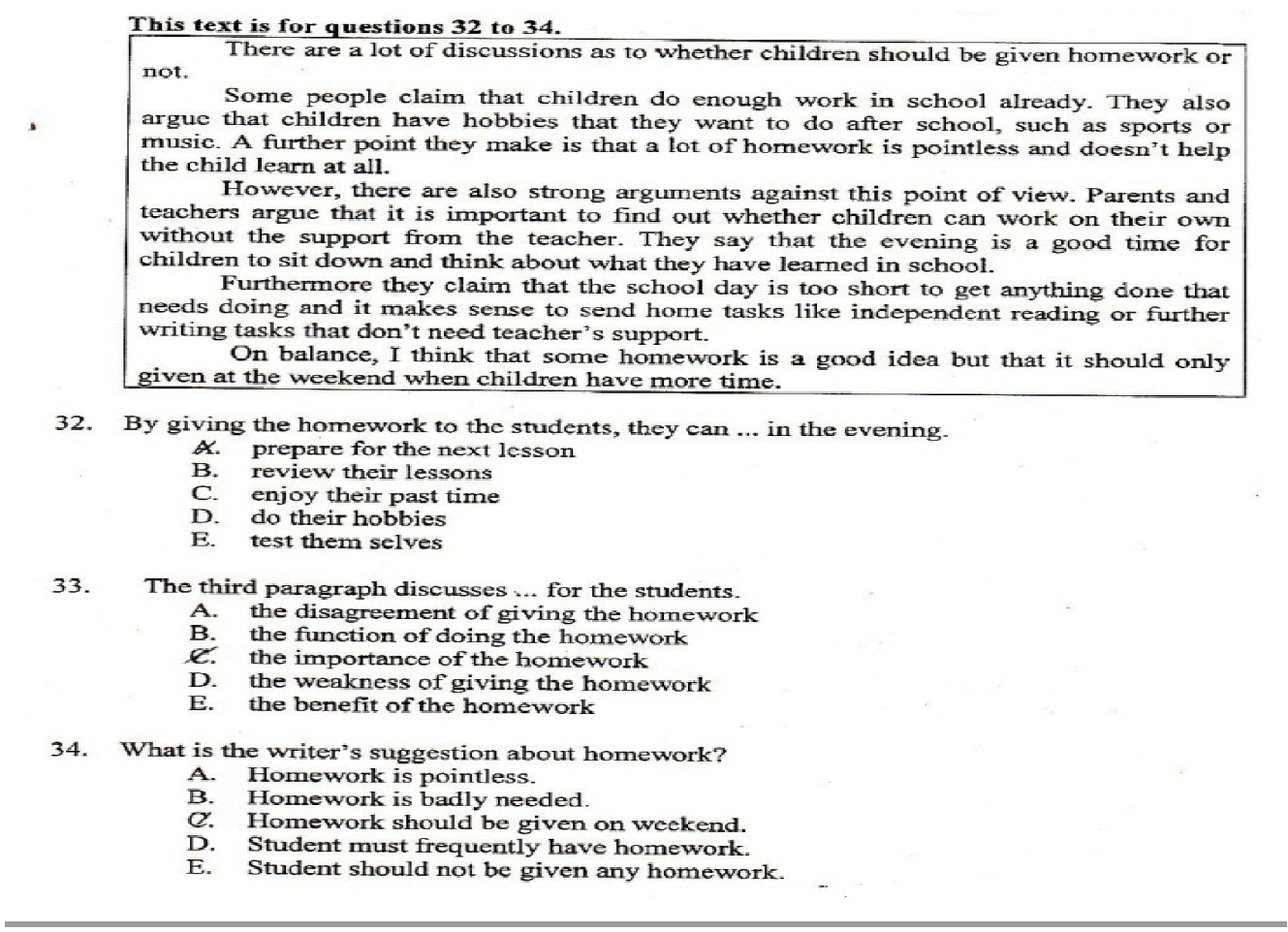

Figure 1.7 Reading questions about discussion 
Not similar to previous texts, the next text is not problematic. A review is presented about martial art performance, followed with three questions which have connections with the text, of course. The following is the complete text:

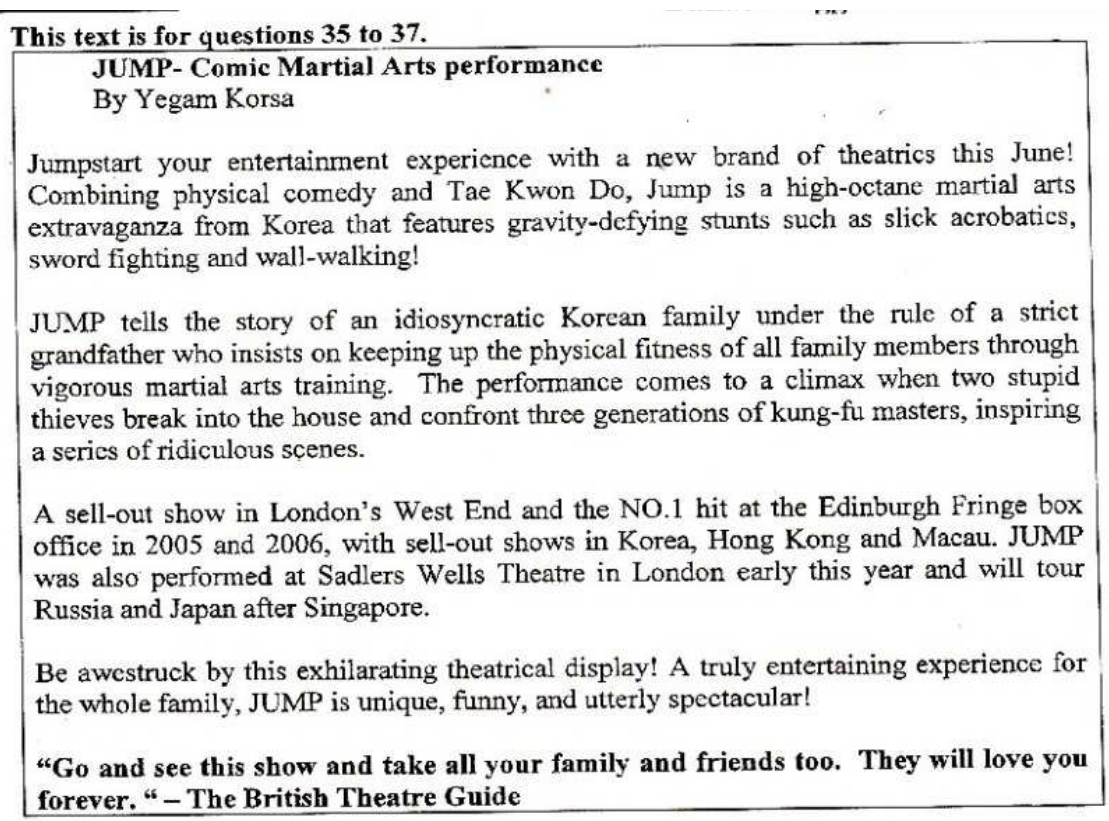

35. The text is about ...

A. entertaining the unique of comic.

B. reviewing the JUMP-Comic Martial Arts.

C. performing the saddlers wells Theatre in London.

D. telling the story of an idiosyncratic Korean family.

E. combining physical comedy and Tae Kwan Do.

36. What is JUMP?
A. It is a series of ridiculous scenes.
B. It is unique, funny, and utterly spectacular.
C. It is a climax when two stupid thieves break into the house
D. It is a truly entertaining experience for the rest of the family.
E. It is a high-octane martial arts extravaganza from Korea featuring gravity- defying stunts.

37. From text, we can imply that JUMP ...
$\mathcal{A}$. is an interesting martial art performing not only physical ability but also self- defense performances.
B. is not a comedy activities but it is only self-defense performances.
C. is a visual activity performing sword fighting only.
D. is not a good show because il does not express anything.
E. is a good martial art.

\section{Figure 1.8 Reading questions about review}




\section{EduLite}

After a review, there is an exposition which is delivered to the students. Again, there are some weaknesses regarding the text, particularly in the last paragraph. It only comprises one sentence which is not enough for supporting a paragraph. In addition, there is an error dealing with the use of comma after the word although. In fact, the sentence is not beautifully formed in the structure. Let us take a look on the text below:

\section{The following text is for questions 38 to 40 .}

Internet has been the most outstanding invention in the history of mankind. With internet, our earth has become a global village. Yet, like many other human made technologies, it has its own advantages and disadvantages.

There are plenty of software that can entertain us or help us to communicate with our beloved ones. In a mere second, we can chat for hours with a person who is sitting at the other parts of the world, read our e-mail in our smart phone or listen to our favorite radio broadcast by streaming it on our tablet.

With its easy access, internet also has its disadvantages. One of them is children may be exposed to violence and explicit contents that only suitable for adults. There are thousands of such inappropriate contents on the internet which can be easily found. It is a very serious issue and may harm children well-being.

Although, internet can create havoc and destruction, its advantages are more important than its disadvantages.

\section{Figure 1.9 Reading text about exposition}

Questions number 41 up to 43 are in relation to a report text describing yaks. From the text and the questions, some problems can be yielded. The first one is about paragraphing. The first paragraph is not indented, although the next paragraphs are all indented. This, though not really crucial, results in inconsistency. Then, the sentence used in question number 42 is not well formed, since there are two words which are confusing. Firstly, the use of (s) is not worth it, as the focus is on having, which is singular. Furthermore, the word adopt used is not suitable. Rather, it should be changed into adapt. The more detailed depiction of the text is presented below: 


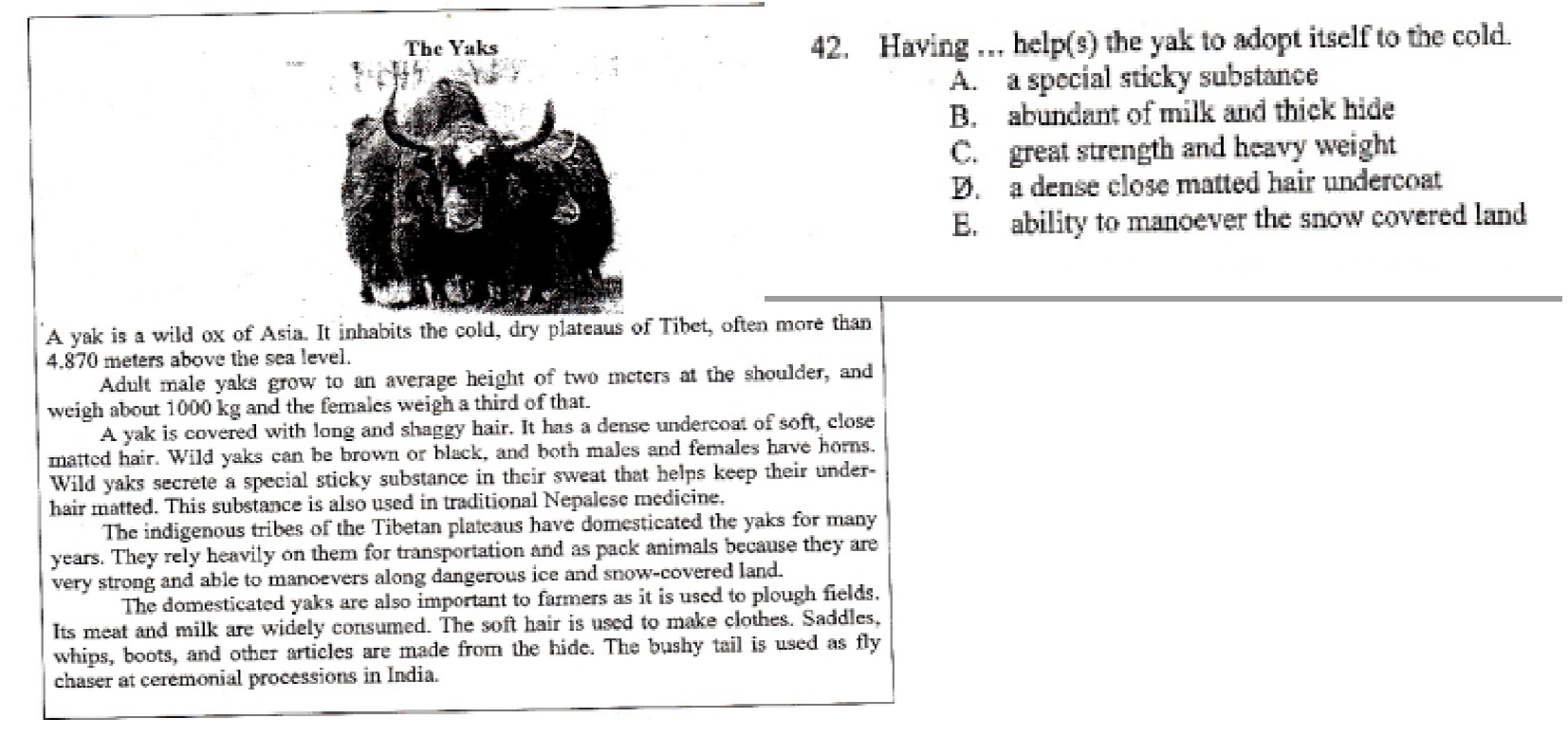

Figure 1.10 Reading questions about report

The last text for reading section in the national examination is announcement about Japan Telkom. Regardless the in-existence of the source of the text, there is nothing to worry, since the text is well structured, and the questions are related to the text. Below gives you the clearer display:

The following text is for questions 44 and 45.

\author{
Company's Name Change
}

Japan Telkom co, Ltd (Head Office: Minato_ku, Tokyo: President and CEO: Hideki Kurashige: hereinafter "Japan Telecom") announces that on October $1^{\text {st }}, 2014$ it will change its name to "Softbank Telecom Corp" and the corporate logo will change to the design used by Softbank Group Companies.

Softbank Group is a comprehensive I.T. network infrastructure, digital platform and content company. With this collective strength, our company offers innovative, board solution which contributes to the business success of our customers.

With this company change, we aim to maximize group synergies to further build the relationship and trust we have with our existing customers. We will use the power of the Softbank Group companies to develop our company's strength.

44. What happened to the company on October $1^{\text {st }}, 2014$ ?
A. It changed its name to Softbank Telecom Corp.
B. It built further relationship with Japan Telkom.
C. It developed its company infrastructure strength
D. It maximized its digital business platform.
E. It changed the company's president and CEO.

45. Softbank Group is ....
A. a technology \& information company
B. the group synergies company
C. the logo design company
D. the contents company
E. Japan company

\title{
Figure 1.11 Reading questions about announcement
}




\section{EduLite}

Journal of English Education, Literature, and Culture

Volume 1, Number 2, August 2016

After reading phase, the students are given writing test, although they are not really asked to write. The blueprints are provided below:

\begin{tabular}{|llr|}
\hline 3 & WRITING (Menulis) & Menyusun beberapa kalimat \\
Mengungkapkan makna secara tertulis & secara acak menjadi sebuah \\
secara formal maupun informal dalam & teks & berbentuk \\
konteks kehidupan sehari-hari, dalam & recount/procedure/narrative/ \\
bentuk teks fungsional pendek atau esai & descriptive dan report. \\
\cline { 2 - 3 } berbentuk recount, narrative, procedure, & Melengkapi 3 rumpang pada \\
descriptive dan report. & teks pendek berbentuk recount/ \\
& procedure/narrative/descriptive \\
& /report dengan kosa kata/frasa \\
& yang sesuai.
\end{tabular}

Table 1.2 Writing Blueprints

There are 5 questions which are divided into two categorisations: ordering sentences into a good plot/ paragraph, and filling in the blanks. The first category looks fine, although it also lacks its source.

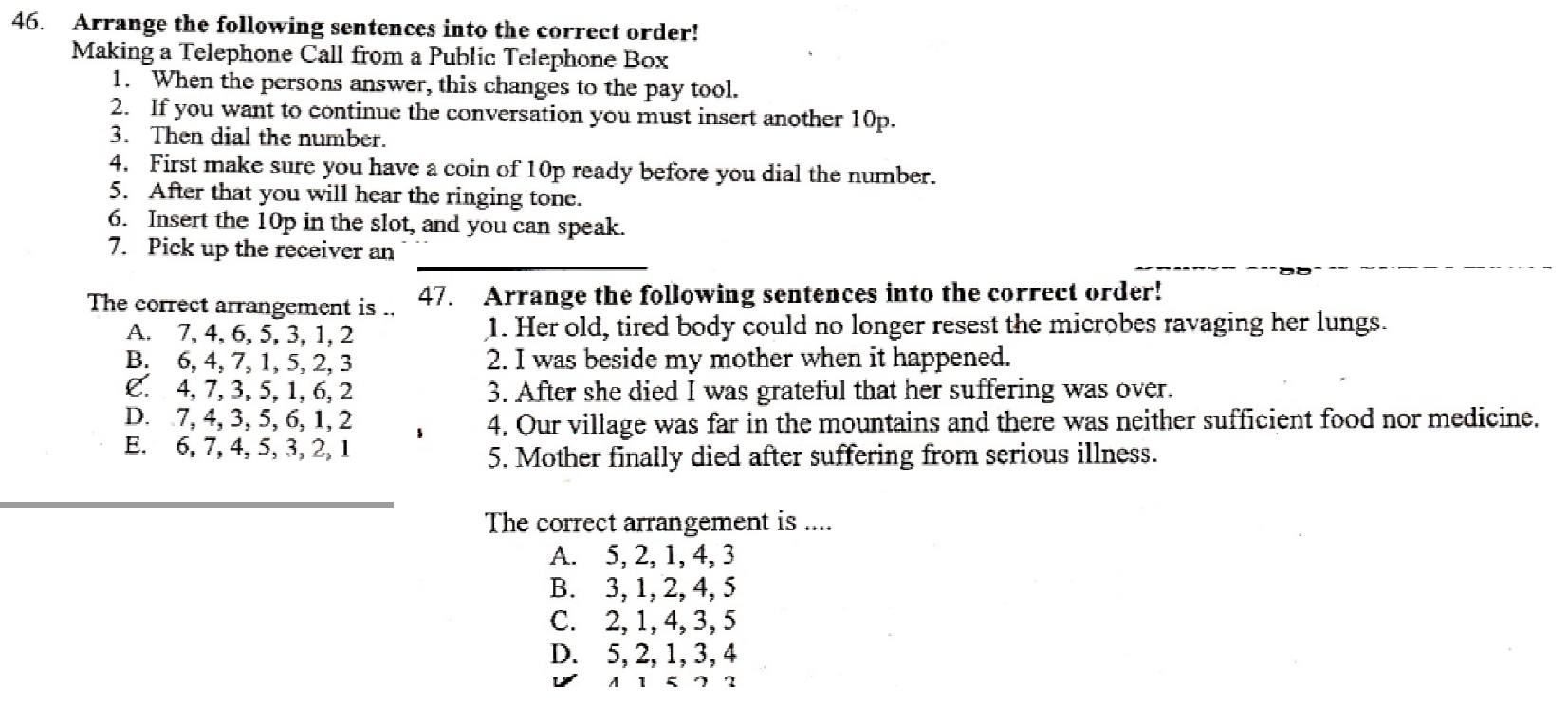

\section{Figure 1.12 Writing questions}

In contrast, the second category is not so perfect for a national examination. The text tells about recount. However, there is a sentence, in which the word for number 48 is missing, does not follow the appropriate tense. Instead of using past tense, the sentence in fact uses present tense. The proof is given below: 
Sabrina, A Language Assessment Analysis of English National Examination Questions 48 to 50, complete the following text with the words provided. Henry and Mary had just married and everybody was enjoying their wedding party.
There was plenty to eat and plenty to drink. Everybody is (48) ... very cheerful,
when a very thin young man come into the room. He looked at Mary (49) ... and
accusingly, walked slowly towards her, kissed her lovingly, and said, "Why did you
do it?" Then he walked to the (50) ... and disappeared. Nobody had ever seen the
young man before-not even Mary.

\section{Figure 1.13 Writing questions}

Next is about regulation analysis. It is aforementioned that the national examination in the academic year of 2014-2015 is published as the examination which does not determine the students' graduation from their schools. Instead, only the school examination and the students' achievement report are used for weighing means. Regarding this, there are some positive impacts and negative ones. The first positive impact is the students' fear freedom of the three-day non sense national examination which becomes one of the factors or even the only factor in determining their destiny. Then, as the national examination is not scary any longer, the students can work hard by themselves to do the examination. As a consequence, the best results reflecting the students' ability in understanding materials can be obviously seen without too much worry on their cheating. Furthermore, it can be feedback for the teachers, as the students' scores will also reflect on the teacher's material delivery. On the contrary, the new regulation has also some negative impacts. The first one is that the schools might do the students' scores marking-up in the achievement report and the school examination in order for all the students to pass. It is not a guess, somehow, because there is an informant who is a teacher in a senior high school in central Java who acknowledges the phenomenon. It might be caused by the school reputation which must be kept great. Next, to some extent, the students, seeing that the national examination is not demanding anymore, will learn and finish the examination without any burden. But, to some extent, the students might be lazy to learn. Instead, they might pay attention more on the school examination only.

Furthermore, some points in the regulation are also beneficial for the students. The report given to the students at the end of the test covers not 


\section{EduLite}

Journal of English Education, Literature, and Culture

only the score of the subject, but also the score mapping and description of each sub competency tested. These additional matters might give fruitful washback to both the students and the teacher. The students can see what is weak and strong for them related to the materials. Consequently, they can improve their weaknesses directly. Then, the teacher can also learn from twhat material is the most difficult faced by the students. From this, the teacher can also do improvement in teaching the materials. Besides the score mapping and description, there is also remedial test. It is very beneficial in terms of the means in motivating the students to improve their score and understanding towards the materials.

\section{CONCLUSION}

It has been explored about the analysis of English national examination in Indonesia in the academic year of 2014-2015. Some weaknesses still emerge regarding the quality of both the text and the questions, also the aspects outside those ones. In relation to the practicality, the questions are proven to be practical, as the multiple choice type is used, making the answers are always practical and even reliable. This, thus, covers the reliability matter. Validity becomes the next concern. All of the questions and texts are indicated to fit the blueprints shared among the students from the government. In addition, the national examination gives the students and the teacher washback as the results also attach the score mapping and description of each sub competency tested. Additionally, the remedial test or examination gives the students a second change to improve their scores and to gain their success into material understanding betterment.

From all of the results, there are some suggestions proposed. The first one is related to the improvement of the text and the questions. It is hoped that these aspects will be mrore perfect in coherence, cohesion, diction, authenticity, until the attachment of the source. The second one is related to the students' and the schools' mental development. This is all about what will happen before and after national examination. The government is expected to motivate the students to keep their spirit in doing national examination and 
Sabrina, A Language Assessment Analysis of English National Examination

the remedial test, in case there are some students who want to improve their scores. Likewise, the schools are also driven to support the fairness in dealing with the scoring of school examination and students' achievement reports.

\section{REFERENCES}

Brandon, Lee, and Kelly Brandon. (2014). Sentences, Paragraphs, and Beyond with Integrated Readings. Boston: Wadsworth.

Brown, H. Douglas. (2000). Language Assessment: Principles and Classroom Practices. New York: Longman.

BSNP. (2014). Peraturan Badan Standar Nasional Pendidikan Nomor: 0027/P/BSNP/IX/2014 Tentang Kisi-Kisi Ujian Nasional untuk Satuan Pendidikan Dasar dan Menengah Tahun Pelajaran 2014/2015. $<$ http://bsnp-indonesia.org/id/wp-content/uploads/2014/10/SKKisi-Kisi-UN-Tahun-Pelajaran-2-14-2015.pdf> as of October 2015.

- (2014). Sosialisasi Kebijakan Ujian Nasional Tahun Pelajaran 2014/2015. <http://bsnp-indonesia.org/id/wpcontent/uploads/2015/03/v.10032015-SOSIALISASI-UJIAN-

NASIONAL-TAHUN-20153-Maret-2015-edit1.pptx> as of October 2015.

Connelly, Mark. (2013). Get Writing: Sentences \& Paragraphs (3 ${ }^{\text {rd }}$ Ed.). Boston: Wadsworth.

Coombe, Christine, et al. (2012). The Cambridge Guide to Second Language Assessment. New York: Cambridge University Press.

Green, Anthony. (2014). Exploring Language Assessment and Testing: Language in Action. New York: Routledge.

Wingersky, Joy, et al. (2009). Writing Paragraphs and Essays: Integrated Reading, Writing, and Grammar Skills (6th Ed.). Boston: Wadsworth. 